\title{
Incomplete Neutralization in Japanese Monomoraic Lengthening
}

\author{
Aaron Braver ${ }^{\mathrm{a}}$ and Shigeto Kawahara ${ }^{\mathrm{b}}$ \\ ${ }^{a}$ Texas Tech University and ${ }^{b}$ Keio University
}

\section{Introduction}

This paper offers a case study of incomplete neutralization of a vowel length contrast in Japanese, and serves as a better-controlled follow up to our previous study (Braver \& Kawahara, 2014). Incomplete neutralization refers to cases in which two segments that are apparently neutralized phonologically are realized with subtle phonetic differences on the surface. A classic case of incomplete neutralization is final devoicing, in which devoiced segments are realized differently than underlyingly voiced segments. For example, Port \& O'Dell (1985) found that in German, ${ }^{1}$ vowels preceding devoiced stops are approximately $15 \mathrm{~ms}$ longer than those before underlying stops. They also found differences in aspiration duration, voicing duration, and closure duration - each of which was consistent (to a reduced degree) with the differences found between voiced and voiceless consonants in non-devoicing contexts cross-linguistically.

Since Port and O'Dell's classic finding, incomplete neutralization has been found in a number of other patterns, including epenthesis in Levantine Arabic (Gouskova \& Hall, 2009), flapping in American English (Braver, 2014), insertion of intrusive stops in English (Fourakis \& Port, 1986), tonal neutralization in Cantonese (Yu, 2007), voicing assimilation in Russian (Burton \& Robblee, 1997), [ə]-insertion in English speakers' pronunciation of non-native clusters (Davidson, 2006), and coda aspiration in Eastern Andalusian Spanish (Gerfen, 2002).

While the vast majority of previously described cases of incomplete neutralization center on featureand segment-level contrasts, our aim is to provide evidence of a novel case of incomplete neutralization in the domain of duration-based length contrasts, further expanding the typology of incomplete neutralization patterns. A few durational phenomena have been alleged to be cases of incomplete neutralization; however, such examples are amenable to reanalysis as more straightforward phonetic processes.

For example, in Chickasaw (Gordon \& Munro, 2007) both underlyingly short and underlyingly long vowels lengthen in final position. Similarly, in St. Lawrence Island Yupik (Krauss 1975, Leer 1985, Hayes 1995:241), Swedish (Bruce 1984, Hayes 1995:84), Tongan (Hayes, 1995:84), and Wargamay (Hayes, 1995:84), there is a reported durational distinction between lengthened short vowels and underlyingly long vowels. Such cases, however, appear to be the result of phonetic stress-based or domain-final lengthening.

Another alleged case of durational incomplete neutralization is found in Kinyarwanda, where a binary short/long vowel length contrast surfaces as three different phonetic durations: short vowels, lengthened short vowels (before NC sequences), and long vowels (Meyers, 2005). However, as Meyers himself argues, the distinction between lengthened and long vowels is best described as phonetic shortening of vowels in closed syllables (Fowler, 1983; Maddieson, 1985). Since this case, too, has a plausible phonetically-based analysis, it is not clear whether it is incomplete neutralization per se.

Given these phonetically-driven cases of subphonemic distinctions, one can ask whether incomplete neutralization has a truly phonological basis at all. One implementation of the pure phonetic view of subphonemic distinctions comes in the form of historical change or drift: two originally distinct phonological categories succumb to phonetic pressures (e.g., coarticulation), causing the distributions of the two categories to, over time, overlap (Pierrehumbert, 2001; Barnes, 2006). Barnes (2006), in fact, argues that all cases of incomplete neutralization are implemented in the phonetics; we intend to show that this is not the case.

\footnotetext{
1 Languages in which incomplete neutralization has been found in final devoicing include Afrikaans (van Rooy et al., 2003), Catalan (Dinnsen \& Charles-Luce, 1984), Dutch (Warner et al., 2004), German (Port \& O'Dell, 1985), Polish (Slowiaczek \& Dinnsen, 1985), and Russian (Dmitrieva, 2005). See Braver (2013) for a more extensive list of references.
} 
To be clear, we do not claim that every subphonemic distinction is purely phonological, but rather than the term 'incomplete neutralization' is best reserved for cases where two phonological categories are phonologically merged, yet result in a subphonemic distinction. In order to establish the phonological nature of an instance of incomplete neutralization, it would have to be shown that a phonological process treats the (phonological) output of the incomplete neutralization as a categorical merger (i.e., the phonology 'sees' the two categories as merged), while at the same time we observe a subphonemic, phonetic distinction (Barnes, 2006:229). We argue that the case of Japanese monomoraic noun lengthening fits this description, and therefore serves as evidence for the phonological nature of at least a subset of the subphonemic distinctions reported in the literature as 'incomplete neutralization'. Incomplete neutralization that is phonologicallybased is potentially of great interest to phonologists, as it presents a challenge to the classical modular feedforward model (Chomsky \& Halle 1968; Bermúdez-Otero 2007; see $\$ 4.2$ for further discussion).

Our study centers on a prosodic constraint in Japanese which requires every Prosodic Word to be minimally bimoraic. When monomoraic nouns appear in isolation, they must lengthen to meet this prosodic minimality requirement (Mori, 2002). The current experiment shows that these lengthened nouns are not as long as underlyingly long nouns - a case of subphonemic distinction. Further, foot-based phenomena such as pitch accent placement are evidenced in both lengthened underlyingly monomoraic and underlyingly bimoraic nouns, suggesting that the lengthening is morphophonological in nature. Because lengthened monomoraic nouns are identical (mora-wise) to underlyingly bimoraic nouns, a difference in duration is not expected. This pattern-phonological identity, but phonetic distinction-is the hallmark of incomplete neutralization. This study expands the typology of incomplete neutralization by showing that duration-based length contrasts can be incompletely neutralized.

\section{Background}

Japanese contrasts short vs. long vowels (e.g., [obasan] 'aunt' vs. [obaasan] 'old lady'). Aspects of this vocalic length contrast have been much studied: for general durational properties of long vowels in Japanese, see Han (1962), Port et al. (1987), Mori (2002), Hirata (2004), and Kawahara \& Braver (2013); for secondary, non-durational acoustic correlates, see Behne et al. (1999), Kinoshita et al. (2002), and Hirata \& Tsukada (2009). These studies show that the length contrast in Japanese is primarily a matter of phonetic duration, with other acoustic cues being only secondary. Hirata (2004), for example, shows that long vowels can be up to $150 \%$ longer than short vowels.

There is a large body of evidence showing that Japanese has a bimoraic minimality requirement on Prosodic Words (Itô, 1990; Poser, 1990; Mester, 1990; Itô \& Mester, 1992; Mori, 2002). The bimoraicity requirement is observed in many word formation patterns, all of which are based on a bimoraic template, including nickname formation, geisha client name formation, loanword abbreviation, verbal root reduplication, scheduling compounds, and telephone number recitation.

For instance, in the nickname formation pattern, a full name is truncated to two moras before the suffix - chan $^{2}$ can be applied. For example, the five-mora name Wasaburoo can be truncated to two moras as in (1b), but not one as in (1c). Similarly, the three-mora name Kotomi can be truncated to either two monomoraic syllables as in (2b), or a single bimoraic syllable, as in (2c). Kotomi cannot, however, be shortened to a single mora, as in (2d).
a. wasaburoo (full name)
b. wasa(-chan) (2 moras)
c. *wa(-chan) (1 mora)
a. kotomi
(full name)
b. koto(-chan)
(2 moras)
c. $\operatorname{koc}(-\mathrm{chan})$
(geminate; 2 moras)
d. *ko(-chan)
(1 mora)

The bimoraicity requirement is evident, too, in telephone number recitation patterns (Itô, 1990). In the recitation of telephone numbers, monomoraic digits (e.g. $n i$ 'two') are lengthened, as in (3a). Additionally, those digits which have both a monomoraic and a bimoraic allomorph (e.g., shi yon 'four') always surface as the bimoraic allomorph, as in (3b).

\footnotetext{
2 Here and throughout, Japanese morphemes are given in the Romaji romanization, except when enclosed in [square brackets], in which case they are given in IPA.
} 
3. (a)

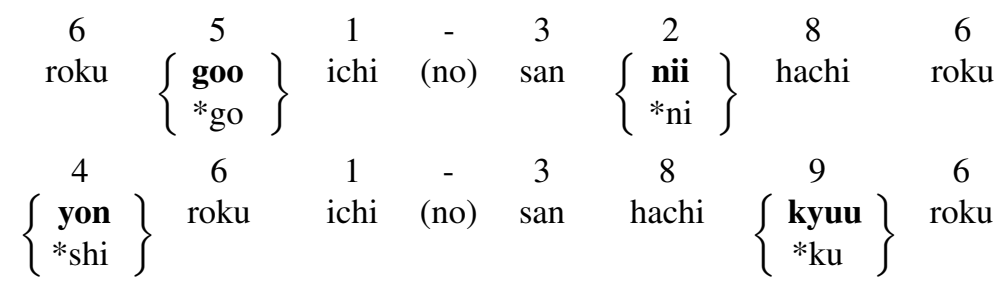

Nickname formation, telephone number recitation, and numerous other morphophonological processes in Japanese are all based on the requirement that a Prosodic Word must be binary at the moraic level (Itô, 1990; Poser, 1990). More specifically, a Prosodic Word must contain at least one foot, and that foot must be binary (McCarthy \& Prince, 1986, 1993) (at the moraic level in Japanese), as in (3).

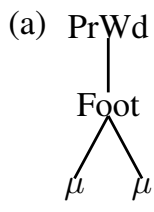

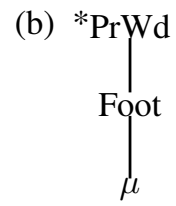

In spite of this bimoraicity requirement, there are monomoraic nouns in the Japanese lexicon, e.g., [ki] 'tree', [i] 'stomach', and [e] 'picture'. Itô (1990) argues that the bimoraic minimality requirement holds only for morphologically derived words. However, Mori (2002) shows that when these monomoraic nouns appear in isolation within a prosodic word (e.g., without case particles and in a non-derived environment), lengthening occurs. She found that monomoraic nouns lengthen in this context by $40-50 \%$, while underlyingly bimoraic nouns do not show such lengthening in the same environment. ${ }^{3}$ Therefore, Mori concludes that the lengthening of monomoraic nouns is caused by a phonological bimoraic minimality requirement: monomoraic nouns with a case particle in the same Prosodic Word satisfy the bimoraicity requirement (by virtue of the particle's mora), as in (4a), while monomoraic nouns must gain an additional mora to satisfy this requirement, as in (4b).

(a) No lengthening with a particle

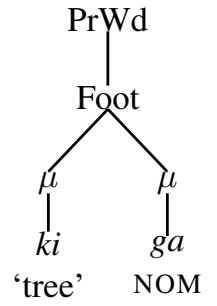

(b) Lengthening without a particle

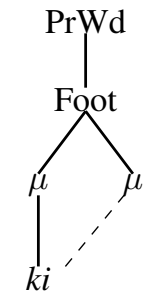

'tree'

Although Mori does not include underlyingly long vowels in her stimulus set, she does refer to previous studies (Beckman, 1982; Hoequist, 1983) which have shown that Japanese heavy syllables are generally 66$80 \%$ longer than light syllables. A more recent phonetic study by Hirata (2004) shows that long vowels in Japanese can be up to $150 \%$ longer than short vowels. This difference between Mori's results (50-50\% longer) and other studies on Japanese length distinctions implies, as Mori herself suggests, that we may be observing a case of incomplete neutralization. The experiment reported below sets out to directly test this hypothesis by comparing the vowel duration of lengthened nouns to that of underlyingly long nouns.

\section{Experiment}

In this experiment, native speakers of Japanese were asked to read sets of sentences. Each set was constructed with a minimal triplet: (a) an underlyingly monomoraic, short noun with a particle, (b) an

\footnotetext{
3 Kubozono \& Ota (1998) note that in the Kinki dialect of Japanese, this lengthening occurs in monomoraic nouns even when not in isolation (i.e., when they are immediately followed by a case particle). See also Haraguchi (1977) and Higuchi \& Haraguchi (2006) for a similar observation.
} 
underlyingly monomoraic noun without a particle, and (c) an underlyingly bimoraic, long noun. From the previous studies discussed above, we expect (i) that monomoraic nouns are lengthened without case particles, as Mori (2002) found, but (ii) that the lengthened nouns are not as long as underlyingly long vowels.

In our previous experiment with a similar setup (Braver \& Kawahara, 2014), we found that this expectation for a three-way length distinction was met. That study, however, failed to control for two factors. First, of the 11 triplets in that task, 5 contained long nouns that were quoted expressives or interjections (e.g.,「ひー」と叫んた。 hii to sakenda "shouted "hii"'), which turned out to be longer than non-quoted long vowels. Second, the frame sentence within a given triplet was not held constant-in other words, the frame sentence used for each condition differed. In so doing, sentence-level mora count was not held constant within a triplet. Both of these factors have been better controlled in the present experiment: no quoted expressives or interjections were used, and frame sentences were held constant throughout a triplet.

\subsection{Method}

3.1.1 Stimuli 15 sets of minimal triplet sentences were constructed, each containing: (a) a monomoraic noun followed by the particle $m o$ ('short/prt' condition), (b) a monomoraic noun without a particle ('short/ ' condition), and (c) an underlyingly long noun without a particle ('long' condition). A sample set is given in Table 1.

\begin{tabular}{lllll}
\hline & Condition & Japanese orthography & Transcription & Gloss \\
\hline (a) & short/prt & 木もなくしたよ。 & ki mo nakushita yo & tree ALSO lost DISC \\
(b) & short/Ø & 木なくしたよ。 & ki nakushita yo & tree lost DISC \\
(c) & long & キーなくしたよ。 & kii nakushita yo & key lost DISC \\
\hline
\end{tabular}

Table 1: Sample stimulus set from the experiment.

Within each set, the nouns' segmental content was identical, with the exception of vowel length in the long condition and the presence of a case particle in the short/prt condition. We used non-approximant consonants as onsets (if present) in the target nouns to facilitate clear segmentation. Our previous study (Braver \& Kawahara, 2014) used the nominative particle $g a$, since it is arguably the default case marker in Japanese subjects (Inoue, 1997). In that study, however, we found that [g] sometimes spirantized to [y], which made the segmentation more difficult. Therefore, in this study, we chose to use the commitative particle $m o$ in the short/prt condition in order to facilitate segmentation. We did not include a particle in the long vowel condition, because our main target comparison was between the short/Ø condition and the long condition, and because Mori (2002) had already shown that long nouns are barely affected in duration by the presence/absence of case particles. ${ }^{4,5}$ All three items within a given set had the same predicate to control for any sentence-level duration compensation effects. The predicate always started with a nonapproximant consonant to make the segmentation more straightforward. A sentence-final discourse particle $y o$ was attached at the end of each sentence to make the stimulus sentences more colloquial, thereby further making the absence of case particles more natural. The list of all the stimuli used in this experiment is provided in the appendix.

3.1.2 Participants Twelve native speakers of Japanese participated in the experiment. They were all undergraduate students at International Christian University (Tokyo, Japan) and were paid $¥ 500$ for their time. Each speaker signed a consent form before participating in the experiment.

3.1.3 Procedure The recording session took place in a sound-attenuated room at International Christian University. We used Superlab version 4.0 (Cedrus Corporation, 2010) to present the stimuli. The stimuli

\footnotetext{
4 Mori (2002) found that bimoraic nouns without case particles lengthened by only $4-5 \%$, as compared to $40-50 \%$ for monomoraic nouns without case particles.

5 Due to an error, one stimulus set contained the particle mo in the long condition. Even with this set excluded from the data, the results described below still hold. See footnote 6 for further discussion.
} 
were written in the standard Japanese orthography, with a mixture of kanji, katakana, and hiragana (see the appendix).

In each block, every stimulus was presented once, and speakers were asked to read the stimuli as they were presented on the screen. The speakers were allowed to take a short break after each block. The order of the stimuli within each block was randomized by Superlab. Each speaker read each sentence a total of 7 times. 30 minutes was allotted for each speaker to complete the experiment.

Before the main session, as practice, each speaker read all the stimuli once to familiarize themselves with the stimuli and the task. After the practice phase, the experimenter (the second author) answered any questions that they had. Their speech was directly recorded onto a portable recorder (TASCAM DR-40) with a 44k sampling rate and a 16 bit quantization level. The second author sat with each speaker throughout the experiment to monitor the progress of the recording.

The duration of each vowel was measured, starting at the offset of the preceding consonant and ending at the end of visible F2/F3, using Praat (Boersma \& Weenink, 2009). The offset of a preceding consonant was marked at the onset of periodic energy and visible formant structure. A representative spectrogram is given in Figure 1 to illustrate our segmentation procedure.

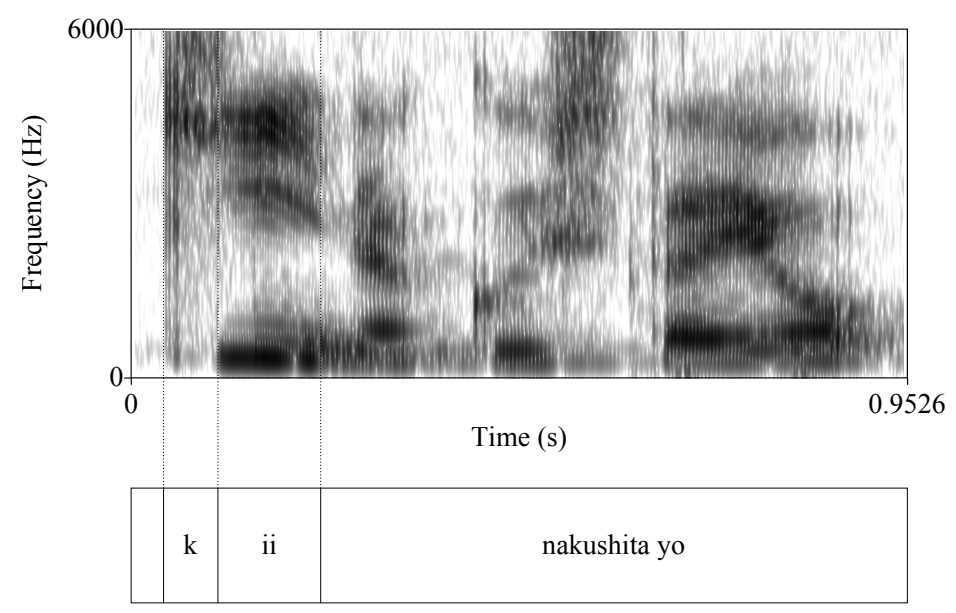

Figure 1: A representative segmented spectrogram. Speaker 43, kii nakushita yo (long), repetition 7.

3.1.4 Statistical analysis Statistical significance was assessed with a linear mixed model (Baayen, 2008) in which vowel duration was regressed against condition (short/prt, short/Ø, long) as a fixed factor and with speaker and item as random factors. Condition was treatment coded to produce comparisons between short/prt vs. short/Ø (to assess whether lengthening occurs) and short/Ø vs. long (to assess whether lengthened nouns are as long as underlyingly long nouns). Since the way to calculate degrees of freedom for these analyses are not yet known (Baayen, 2008), the significance values are calculated by the Markov Chain Monte Carlo method using the pvals. fnc () function of the languageR package (Baayen, 2009). Of a possible 3,780 tokens ( 45 stimuli $\times 7$ repetitions $\times 12$ speakers), 3,668 tokens were included in the analysis - tokens were excluded if the vocalic boundary was unclear enough to judge duration or if speakers accidentally skipped an item.

3.2 Results Figure 2 shows the overall results, averaging over all speakers and all items. Comparison between the first two conditions shows that short nouns are lengthened when they appear without case particles and hence are longer than short nouns that appear with particles (mean difference: $69.98 \mathrm{~ms}$, $t=15.692, p<0.001$ ), replicating Mori's (2002) result. Comparison between the last two conditions, however, shows that the lengthened nouns are not as long as underlyingly long nouns (mean difference: 32.47 $\mathrm{ms}, t=7.047, p<0.001)^{6}{ }^{6}$ Therefore, the Japanese lengthening pattern instantiates a case of incomplete neutralization.

\footnotetext{
6 As per footnote 5, one set contained the particle $m o$ in the long condition. While long tokens in this set were on average $16.21 \mathrm{~ms}$ longer than in other sets $(158.58 \mathrm{~ms}$ vs. $142.37 \mathrm{~ms})$, this difference did not affect the overall results.
} 


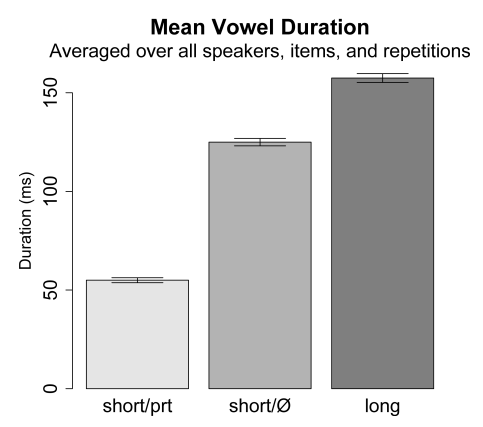

Figure 2: Vowel duration over all speakers and all items.

To investigate whether this tripartite distinction holds across speakers, Figure 3 shows the patterns of all 12 speakers analyzed. We observe that all speakers show incomplete neutralization (with the possible exception of Speaker 44): lengthened nouns are not as long as underlyingly long nouns for any speaker. The two speakers with the smallest mean differences between short/ $\varnothing$ and long vowels were speakers 44 and 46 . The difference for speaker 46 is significant (short/Ø mean: 139.12, long mean: 147.94, mean difference: $8.82, t=19.43, p<0.001)$. The difference for speaker 44 trends in the same direction as the other speakers, but does not reach significance (short/ $\varnothing$ mean: 125.79 , long mean: 131.45 , mean difference: $5.66, t=$ .928, n.s.).
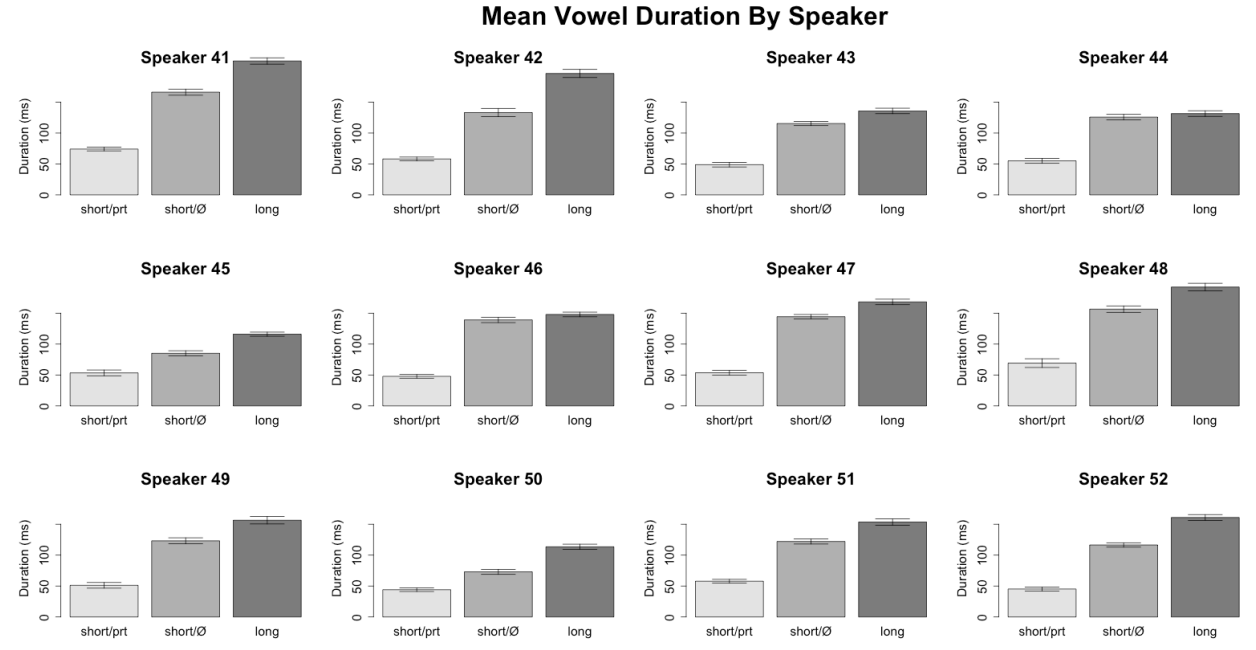

Figure 3: Vowel duration by speaker, averaged across items.

Finally, to investigate the possibility of an item effect, Figure 4 shows a by-item analysis, with results for each of the 15 lexical sets. We again observe that within each set, all short nouns are lengthened without particles, but they are not as long as underlyingly long nouns.

3.3 Discussion: The phonological nature of monomoraic lengthening In the current case, lengthening is motivated by a clearly phonological, rather than phonetic, bimoraic minimality constraint in Japanese. The constraint is deeply tied into the morphophonology of Japanese, as it governs many Japanese morphophonological patterns (Itô, 1990; Poser, 1990; Mester, 1990; Itô \& Mester, 1992; Mori, 2002)— including allomorph selection, as in (3b). Further, the underlyingly monomoraic nouns, when lengthened,

A post-hoc analysis shows that the model remains significant even with the exclusion of this set-short/prt vs. short/Ø: $t=-15.192, p<0.001$; short/Ø vs. long: $t=-6.847, p<0.001$. 

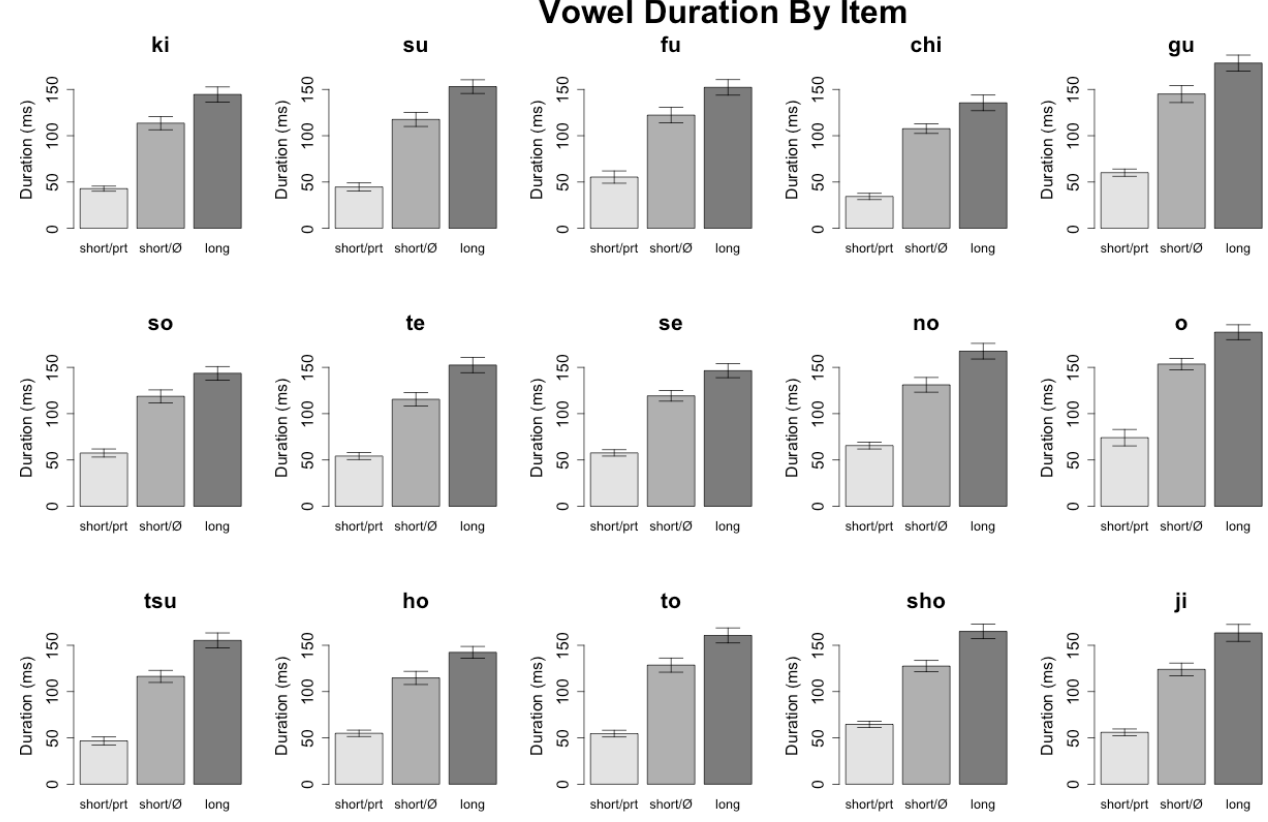

Figure 4: Vowel duration by item, averaged across speakers.

can carry a pitch accent (see below). We thus conclude that lengthening is phonological, as it is triggered by a phonological constraint. Since both lengthened and underlyingly bimoraic nouns are treated as bimoraic by the phonology of Japanese, the case of monomoraic noun lengthening constitutes counterevidence to the view that all incomplete neutralization patterns are phonetic in nature (Barnes, 2006:p. 229).

One piece of evidence which supports the claim that lengthened nouns are, like underlyingly long nouns, bimoraic, comes from haiku. Japanese haiku consist of three lines, with five, seven, and five moras respectively. In the haiku in (5) below, the first word of the last line ( $k i)$ is lengthened to kii after dropping the accusative particle $o$ (not shown; periods indicate mora breaks, rather than syllable boundaries). The lengthened kii fills two moraic slots-the final line counts as 5 moras. This suggests that, at least for poetic purposes, lengthened monomoraic nouns are bimoraic.

$$
\begin{array}{lll}
\text { あしたから } & \text { a.shi.ta ka.ra } & \text { From tomorrow on } \\
\text { みえにしゅっちょう } & \text { mi.e ni shu.c.cho.o } & \text { I have a business trip to Mie } \\
\text { きーつけて } & \text { ki.(i) tsu.ke.te } & \text { Take care }
\end{array}
$$

A further piece of evidence which suggests that the phonology treats lengthened and bimoraic nouns similarly is that both lengthened and bimoraic nouns can carry a pitch accent. In other words, the 'lengthened portion' can carry the L tone of the accentual $\mathrm{H}^{*} \mathrm{~L}$. The tone bearing unit in Japanese is the mora (Haraguchi, 1977; McCawley, 1977) and thus the lengthened vowels must have two moras.

Figure 5 shows pitch tracks for ki nakushita yo (underlyingly monomoraic, but lengthened) and kii nakushita yo (underlyingly bimoraic), both from speaker 41; the two figures look almost identical in terms of the shape of the pitch drop. The pitch tracks both demonstrate the $\mathrm{H}^{*} \mathrm{~L}$ tonal pattern associated with Japanese pitch accent on their first syllable. In particular, the $\mathrm{L}$ tone of the accentual $\mathrm{H}^{*} \mathrm{~L}$ complex lands on the second mora; in lengthened monomoraic nouns this means that the 'lengthened portion' bears the L tone. Additionally, the fact that the bimoraicity requirement can effect even allomorph selection (a clearly morphological process), as in (3), further suggests that monomoraic lengthening has a phonological basis. 

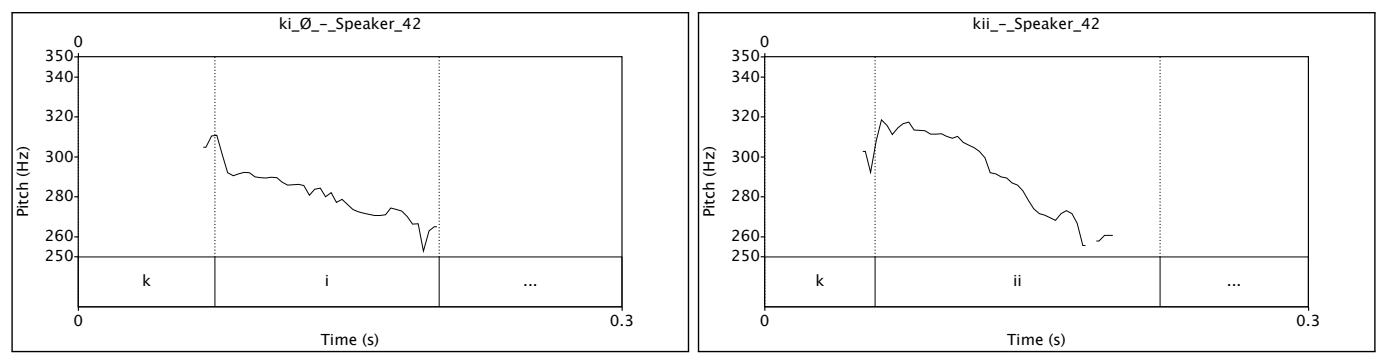

Figure 5: Pitch tracks for stimuli ki kii from speaker 42. Both lengthened $k i$ (left) and underlyingly long kii (right) bear an L tone.

\section{Conclusion}

4.1 General implications The current results suggest that the short/long vowel length distinction in Japanese is incompletely neutralized when monomoraic nouns without case particles are lengthened: these lengthened nouns must have two moras on the surface to meet the Japanese bimoraicity requirement (Itô, 1990; Poser, 1990; Mester, 1990; Itô \& Mester, 1992; Mori, 2002), yet their vowel durations are intermediate between those of underlyingly short and underlyingly long vowels. As an example, take the set given in (6). Since chi mo (short/prt), in (6a), and chii (long), in (6c), both have two underlying moras within their Prosodic Word, no lengthening is required in these conditions. In order to meet the bimoraicity requirement, chi (short/Ø), in (6b) must link to a second additional mora, since there is no other available underlying segmental content. This study shows, however, that lengthened vowels like those in (6b) are not as long as underlyingly long vowels like those in (6c).
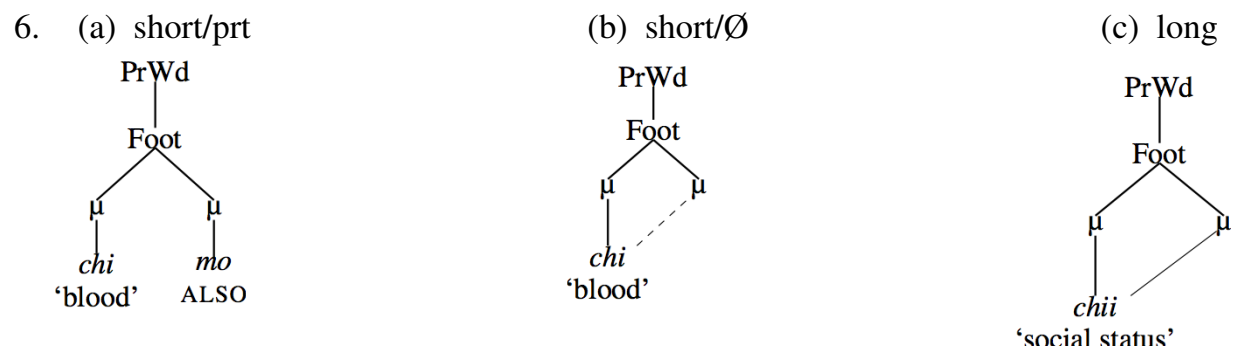

Having established that the Japanese case is indeed a case of incomplete neutralization, some remarks on general theoretical implications are in order. First the current results expand the typology of processes that can lead to incompletely neutralized contrasts to include not just processes at the segment- and feature-level, but also processes motivated by suprasegmental structure. This result is in line with, and perhaps even more robust than, the findings of our previous study (Braver \& Kawahara, 2014).

Second, since the lengthening is triggered by a clearly phonological constraint, it cannot be treated as a matter of phonetic implementation - unlike a number of proposed cases of incomplete neutralization. For example, Ohala (1974) and Fourakis \& Port (1986) treat the case of intrusive stops in English as a matter of phonetic implementation. Similarly, Davidson (2006) treats [ə]-insertion in English speakers' pronunciation of non-native clusters, which results in an apparent case of incomplete neutralization, as resulting from gestural mis-coordination. If the phenomenon in question is a matter of phonetic implementation, it is not strictly speaking a case of incomplete neutralization, as two segments are not neutralized phonologically. In order to prove that a case of a subphonemic distinction is phonological, and not due purely to phonetic factors, it must be shown that phonology treats the two neutralized categories identically (Barnes, 2006:p. 229), as we did in $\S 3.3$.

4.2 Modeling incomplete neutralization Phonologically-based incomplete neutralization poses a problem for classical modular feedforward models (Chomsky \& Halle, 1968; Bermúdez-Otero, 2007). Under 
such models, the two categories being neutralized (in the case of monomoraic lengthening, these are underlyingly bimoraic nouns and lengthened, underlyingly monomoraic nouns) are phonologically neutralized completely - at the level of the phonological output they have the same representation. The phonetic module, which has access only to the phonological output (and not, e.g., to underlying representations), should therefore realize these two categories identically. In incomplete neutralization, though, slight differences remain on the surface.

In an early attempt to reconcile this issue Anderson (1975) suggests that phonetic and phonological rules should be interleaved, rather than phonetic rules always applying after phonological rules. At the time a phonetic rule applies, then, the phonological neutralization may not yet have taken place. As such, we might expect a gradient process to distinguish two categories which will later be rendered phonologically identical.

A more recent alternative is to give the two categories different representations in the phonological output. van Oostendorp (2008), in an analysis of incomplete neutralization in final devoicing, suggests that segments can stand in two types of relations with underlying feature values - the abstract structural 'projection' relation and the 'pronunciation' relation. Underlyingly voiceless segments have no relation to an underlying [voice] feature, while devoiced segments are in a projection relationship with an underlying [voice] feature. The phonetics, then, can differentiate between underlyingly voiceless and devoiced segments, resulting in incomplete neutralization.

Yet another approach suggests that the phonology has relatively fine-grained control over the phonetic implementation of contrasts (Yu, 2011). This approach, following Kingston \& Diehl (1994:420 fn. 2) allows contrastive features to vary in their realization depending on their context. For example [+voice] in English may be realized with closure voicing intervocalically, but as voiceless unaspirated word-initially. $\mathrm{Yu}$ (2011) argues that subphonemic differences such as incomplete neutralization (and near merger) may be modeled along these lines - the two categories remain phonologically distinct, even if the phonetic cues to that distinction in a given context are so impoverished as to "escape detection by traditional methods of linguistic data collection..." (p. 311).

A final approach (Braver, 2013) models incomplete neutralization with a combination of weighted phonetic constraints (Zsiga, 2000; Flemming, 2001) and paradigm uniformity (Benua, 1997; Steriade, 2000). In this model, the tension between paradigm uniformity (i.e., faithfulness to a morphological relative) and complete neutralization yield the subphonemic distinctions that are the hallmark of incomplete neutralization. With appropriate constraint weightings, this approach can account for incomplete neutralization in a wide variety of contexts. This model is discussed in greater detail in Braver (2013) and Braver \& Kawahara (to appear).

4.3 Final remarks We conclude with two brief remarks. First, we note that the typology of processes susceptible to incomplete neutralization must be expanded to include processes-like monomoraic noun lengthening - that affect a contrast of length or prosodic structure. Second, incomplete neutralization —at least in this case - cannot be reduced to a question of phonetic implementation (cf. Barnes, 2006). Rather, the phonology must play a role by allowing phonetics to distinguish two phonologically neutralized segments.

\section{Appendix: Stimuli from Experiment}

\begin{tabular}{|c|c|c|}
\hline Japanese orthography & Transcription & Gloss \\
\hline $\begin{array}{l}\text { 木もなくしたよ。 } \\
\text { 木なくしたよ。 } \\
\text { キーなくしたよ。 }\end{array}$ & $\begin{array}{l}\text { ki' mo nakushita yo } \\
\text { ki' nakushita yo } \\
\text { ki'i nakushita yo }\end{array}$ & $\begin{array}{l}\text { tree ALSO lost DISC } \\
\text { tree lost DISC } \\
\text { key lost DISC }\end{array}$ \\
\hline $\begin{array}{l}\text { 酢も見つけたよ。 } \\
\text { 酢見つけたよ。 } \\
\text { スー見つけたよ。 }\end{array}$ & $\begin{array}{l}\text { su' mo mitsuketa yo } \\
\text { su' mitsuketa yo } \\
\text { su'u mitsuketa yo }\end{array}$ & $\begin{array}{l}\text { vinegar ALSO found DISC } \\
\text { vinegar found DISC } \\
\text { Sue found DISC } \\
\qquad \text { (continued...) }\end{array}$ \\
\hline
\end{tabular}




\begin{tabular}{|c|c|c|}
\hline Japanese orthography & Transcription & Gloss \\
\hline $\begin{array}{l}\text { 麥も残したよ。 } \\
\text { 麩残したよ。 } \\
\text { 封残したよ。 }\end{array}$ & $\begin{array}{l}\text { fu mo nokoshita yo } \\
\text { fu nokoshita yo } \\
\text { fu'u nokoshita yo }\end{array}$ & $\begin{array}{l}\text { gluten ALSO left DISC } \\
\text { gluten left DISC } \\
\text { seal left DISC }\end{array}$ \\
\hline $\begin{array}{l}\text { 血も捧げたよ。 } \\
\text { 血捧げたよ。 } \\
\text { 地位捧げたよ。 }\end{array}$ & $\begin{array}{l}\text { chi mo sasageta yo } \\
\text { chi sasageta yo } \\
\text { chi'i sasageta yo }\end{array}$ & $\begin{array}{l}\text { blood ALSO dedicated DISC } \\
\text { blood dedicated DISC } \\
\text { social.status dedicated DISC }\end{array}$ \\
\hline $\begin{array}{l}\text { 具も出したよ。 } \\
\text { 具出したよ。 } \\
\text { グー出したよ。 }\end{array}$ & $\begin{array}{l}\text { gu mo dashita yo } \\
\text { gu dashita yo } \\
\text { gu'u dashita yo }\end{array}$ & $\begin{array}{l}\text { ingredients ALSO gave DISC } \\
\text { ingredients gave DISC } \\
\text { fist gave DISC }\end{array}$ \\
\hline $\begin{array}{l}\text { ソも確かめたよ。 } \\
\text { ソ確かめたよ。 } \\
\text { 層確かめたよ。 }\end{array}$ & $\begin{array}{l}\text { so' mo tashikameta yo } \\
\text { so' tashikameta yo } \\
\text { so'u [soo] tashikameta yo }\end{array}$ & $\begin{array}{l}\text { so ALSO confirmed DISC } \\
\text { so confirmed DISC } \\
\text { layer confirmed DISC }\end{array}$ \\
\hline $\begin{array}{l}\text { 手も測ったよ。 } \\
\text { 手測ったよ。 } \\
\text { 低測ったよ。 }\end{array}$ & $\begin{array}{l}\text { te' mo hakatta yo } \\
\text { te' hakatta yo } \\
\text { te'i [tee] hakatta yo }\end{array}$ & $\begin{array}{l}\text { hand ALSO measured DISC } \\
\text { hand measured DISC } \\
\text { base measured DISC }\end{array}$ \\
\hline $\begin{array}{l}\text { 背も違うよ。 } \\
\text { 背違うよ。 } \\
\text { 性違うよ。 }\end{array}$ & $\begin{array}{l}\text { se' mo chigau yo } \\
\text { se' chigau yo } \\
\text { se'i } \text { [see] chigau yo }\end{array}$ & $\begin{array}{l}\text { height ALSO is-different DISC } \\
\text { height is-different DISC } \\
\text { gender is-different DISC }\end{array}$ \\
\hline $\begin{array}{l}\text { 野も持ってるよ。 } \\
\text { 野持ってるよ。 } \\
\text { 脳持ってるよ。 }\end{array}$ & $\begin{array}{l}\text { no' mo motteru yo } \\
\text { no' motteru yo } \\
\text { no'u [noo] motteru yo }\end{array}$ & $\begin{array}{l}\text { field ALSO have DISC } \\
\text { field have DISC } \\
\text { brain have DISC }\end{array}$ \\
\hline $\begin{array}{l}\text { 尾も出てきたよ。 } \\
\text { 尾出てきたよ。 } \\
\text { 王出てきたよ。 }\end{array}$ & $\begin{array}{l}\text { o' mo detekita yo } \\
\text { o' detekita yo } \\
\text { o'u detekita yo }\end{array}$ & $\begin{array}{l}\text { tail ALSO appeared DISC } \\
\text { tail appeared DISC } \\
\text { king appeared DISC }\end{array}$ \\
\hline $\begin{array}{l}\text { 津も買収したよ } \\
\text { 津買収したよ } \\
\text { 通買収したよ。 }\end{array}$ & $\begin{array}{l}\text { tsu' mo baishuushita yo } \\
\text { tsu' baishuushita yo } \\
\text { tsu'u baishuushita yo }\end{array}$ & $\begin{array}{l}\text { Tsu ALSO bought/bought.off DISC } \\
\text { Tsu bought/bought.off DISC } \\
\text { expert bought/bought.off DISC }\end{array}$ \\
\hline $\begin{array}{l}\text { 帆も叨いたよ。 } \\
\text { 帆叮いたよ。 } \\
\text { ほおも叮いたよ。 }\end{array}$ & $\begin{array}{l}\text { ho' mo tataita yo } \\
\text { ho' tataita yo } \\
\text { ho'o }(\mathrm{mo})^{7} \text { tataita yo }\end{array}$ & $\begin{array}{l}\text { sail ALSO hit DISC } \\
\text { sail hit DISC } \\
\text { cheek hit DISC }\end{array}$ \\
\hline $\begin{array}{l}\text { 都も独占したよ。 } \\
\text { 都独占したよ。 } \\
\text { 塔独占したよ。 }\end{array}$ & $\begin{array}{l}\text { to' mo dokusenshita yo } \\
\text { to' dokusenshita yo } \\
\text { to'u [too] dokusenshita yo }\end{array}$ & $\begin{array}{l}\text { city ALSO monopolized DISC } \\
\text { city monopolized DISC } \\
\text { tower monopolized DISC }\end{array}$ \\
\hline $\begin{array}{l}\text { 書も独占したよ。 } \\
\text { 書独占したよ。 } \\
\text { 章独占したよ。 }\end{array}$ & $\begin{array}{l}\text { sho' mo dokusenshita yo } \\
\text { sho' dokusenshita yo } \\
\text { sho'u [joo] dokusenshita yo }\end{array}$ & $\begin{array}{l}\text { book ALSO monopolized DISC } \\
\text { book monopolized DISC } \\
\text { chapter monopolized DISC }\end{array}$ \\
\hline $\begin{array}{l}\text { 字も公開したよ。 } \\
\text { 字公開したよ。 } \\
\text { 爺公開したよ。 }\end{array}$ & $\begin{array}{l}\text { ji' mo koukaishita yo } \\
\text { ji' koukaishita yo } \\
\text { ji'i koukaishita yo }\end{array}$ & $\begin{array}{l}\text { letter ALSO publicized DISC } \\
\text { letter publicized DISC } \\
\text { grandpa publicized DISC }\end{array}$ \\
\hline
\end{tabular}

All stimulus sets from the Experiment. Target nouns are in boldface. Accents, represented with an apostrophe following the accented syllable, are shown for target nouns only.

7 In the long condition of ho'/ho'o, the particle $m o$ was included by mistake. See footnotes 5 and 6 for discussion. 


\section{References}

Anderson, Stephen R. (1975). On the interaction of phonological rules of various types. Journal of Linguistics 11:1, 39-62.

Baayen, Harald (2008). Analyzing Linguistic Data: A Practical Introduction to Statistics Using R. Cambridge University Press, Cambridge.

Baayen, Harald (2009). languager: Data sets and functions with "analyzing linguistic data: A practical introduction to statistics". R package, URL http: / / CRAN.R-project. org/package=languageR.

Barnes, Jonathan (2006). Strength and weakness at the interface: Positional neutralization in phonetics and phonology. Mouton de Gruyter, Berlin/New York.

Beckman, Mary (1982). Segmental duration and the 'mora' in Japanese. Phonetica 39, 113-135.

Behne, D., T. Arai, P. Czigler \& K. Sullivan (1999). Vowel duration and spectra as perceptual cues to vowel quantity: A comparison of Japanese and Swedish. Proceedings of ICPhS 1999 857-860.

Benua, Laura (1997). Transderivational Identity: Phonological Relations between Words. Doctoral dissertation, University of Massachusetts, Amherst.

Bermúdez-Otero, Ricardo (2007). Diachronic phonology. de Lacy, Paul (ed.), The Cambridge Handbook of Phonology, Cambridge University Press, Cambridge, 497-517.

Boersma, Paul \& David Weenink (2009). Praat: Doing phonetics by computer. Computer program, URL http: / / www . praat.org.

Braver, Aaron (2013). Degrees of Incompleteness in Neutralization: Paradigm Uniformity in a Phonetics with Weighted Constraints. Ph.D. thesis, Rutgers, The State University of New Jersey, New Brunswick, NJ.

Braver, Aaron (2014). Imperceptible incomplete neutralization: Production, identification, and discrimination of /d/ and /t/ flaps in American English. Lingua 152, 24-44.

Braver, Aaron \& Shigeto Kawahara (2014). Incomplete vowel lengthening in Japanese: A first study. Santana-LaBarge, Robert E. (ed.), Proceedings of the 31st Meeting of the West Coast Conference on Formal Linguistics, Cascadilla Press, Somerville, MA.

Braver, Aaron \& Shigeto Kawahara (to appear). Incomplete neutralization via paradigm uniformity and weighted constraints. Proceedings of North Eastern Linguistic Society (NELS) 45.

Bruce, Gösta (1984). Rhythmic alternation in Swedish. Elert, Claes-Christian, Irene Johansson \& Eva Strangert (eds.), Nordic prosody III, University of Umeå, 31-41.

Burton, Martha W. \& Karen E. Robblee (1997). A phonetic analysis of voicing assimilation in Russian. Journal of Phonetics 25:2, 97-114.

Cedrus Corporation (2010). Superlab v. 4.5. Computer program.

Chomsky, Noam \& Morris Halle (1968). The Sound Pattern of English. Harper and Row, New York.

Davidson, Lisa (2006). Phonology, phonetics, or frequency: Influences on the production of non-native sequences. Journal of Phonetics 34, 104-137.

Dinnsen, Daniel \& Jan Charles-Luce (1984). Phonological neutralization, phonetic implementation and individual differences. Journal of Phonetics 12, 49-60.

Dmitrieva, Olga (2005). Incomplete Neutralization in Russian Final Devoicing: Acoustic Evidence from Native Speakers and Second Language Learners. Master's thesis, University of Kansas, Lawrence, Kansas.

Flemming, Edward (2001). Scalar and categorical phenomena in a unified model of phonetics and phonology. Phonology $18,7-44$.

Fourakis, Marios \& Robert Port (1986). Stop epenthesis in English. Journal of Phonetics 14:2, 197-221.

Fowler, Carol A. (1983). Converging sources of evidence on spoken and perceived rhythms of speech: Cyclic production of vowels in sequences of monosyllabic stress feet. Journal of Experimental Psychology: General 112, 386-412.

Gerfen, Chip (2002). Andalusian codas. Probus 14, 247-277.

Gordon, Matthew \& Pamela Munro (2007). A phonetic study of final vowel lengthening in Chickasaw. International Journal of American Linguistics 7:3, 293-330.

Gouskova, Maria \& Nancy Hall (2009). Acoustics of unstressable vowels in Lebanese Arabic. Parker, Steve (ed.), Phonological Argumentation: Essays on Evidence and Motivation, Equinox Books.

Han, Mieko (1962). The feature of duration in Japanese. Onsei no Kenkyuu [Studies in Phonetics] 10, 65-80.

Haraguchi, Shosuke (1977). The Tone Pattern of Japanese: An Autosegmental Theory of Tonology. Kaitakusha, Tokyo.

Hayes, Bruce (1995). Metrical Stress Theory: Principles and Case Studies. University of Chicago Press.

Higuchi, Marii \& Shosuke Haraguchi (2006). Final lengthening in Japanese. On-in Kenkyu [Phonological Studies] 9, 9-16.

Hirata, Yukari (2004). Effects of speaking rate on the vowel length distinction in Japanese. Journal of Phonetics 32:4, $565-589$.

Hirata, Yukari \& Kimiko Tsukada (2009). Effects of speaking rate and vowel length on formant frequency displacement in Japanese. Phonetica 66, 129-149.

Hoequist, Charles E. (1983). Durational correlates of linguistic rhythm categories. Phonetica 40, 19-31. 
Inoue, Kazuko (1997). Case marking vs. Case checking in Japanese generative grammar: An alternative proposal. Proceedings of the electronic conference "The 40th Anniversary of Generativism", Web Journal of Formal, Computational, \& Cognitive Linguistics, FCCL, URL http: / / fCCl.ksu.ru/papers/inoue.htm.

Itô, Junko (1990). Prosodic minimality in Japanese. Ziolkowski, Michael, Manual Noske \& Karen Deaton (eds.), Proceedings of Chicago Linguistic Society 26: Parasession on the Syllable in Phonetics and Phonology, Chicago Linguistic Society, Chicago, 213-239.

Itô, Junko \& Armin Mester (1992). Weak layering and word binarity. Ms. University of California, Santa Cruz.

Kawahara, Shigeto \& Aaron Braver (2013). The phonetics of emphatic vowel lengthening in Japanese. Open Journal of Modern Linguistics 3:2, 141-148.

Kingston, John \& Randy L Diehl (1994). Phonetic knowledge. Language 3, 419-454.

Kinoshita, K., D. Behne \& T. Arai (2002). Duration and F0 as perceptual cues to Japanese vowel quantity. Proceedings of ICSLP 757-760.

Krauss, Michael E. (1975). St. lawrence island eskimo phonology and orthography. Linguistics 13:152, $39-72$.

Kubozono, Haruo \& Satoshi Ota (1998). On'in Koozoo to Akusento [Phonological structure and accent]. Kenkyusha, Tokyo.

Leer, Jeff (1985). Prosody in alutiiq. Kraus, M. (ed.), Yupik Eskimo Prosodic Systems: Descriptive and Comparative Studies, Alaska Native Language Center Research Papers no. 7, Alaska Native Language Center, University of Alaska, Fairbanks, 77-133.

Maddieson, Ian (1985). Phonetic cues to syllabification. Fromkin, Victoria (ed.), Phonetic Linguistics, Academic Press, London, 203-221.

McCarthy, John J. \& Alan Prince (1986). Prosodic morphology. Ms. University of Massachusetts and Rutgers University.

McCarthy, John J. \& Alan Prince (1993). Prosodic morphology: Constraint interaction and satisfaction, URL ROA 482. RuCCS-TR-3.

McCawley, James D. (1977). Accent in Japanese. Hyman, Larry (ed.), Studies in Stress and Accent, Southern California Occasional Papers in Linguistics 4, USC, Los Angeles, 261-302.

Mester, Armin (1990). Patterns of truncation. Linguistic Inquiry 21, 475-485.

Meyers, Scott (2005). Vowel duration and neutralization of vowel length contrasts in Kinyarwanda. Journal of Phonetics $33: 4,427-446$.

Mori, Yoko (2002). Lengthening of Japanese monomoraic nouns. Journal of Phonetics 30:4, 689-708.

Ohala, John J. (1974). Experimental historical phonology. Naderson, J. M. \& Charles Jones (eds.), Historical Linguistics II: Theory and Description in Phonology. Proceedings of the First International Linguistic Conference on Historical Linguistics, Elsevier, New York, 353-389.

van Oostendorp, Marc (2008). Incomplete devoicing in formal phonology. Lingua 118, 1362-1374.

Pierrehumbert, Janet B. (2001). Stochastic phonology. GLOT International 5:6, 195-207.

Port, Robert \& Michael O'Dell (1985). Neutralization and syllable-final voicing in German. Journal of Phonetics 13, $455-471$.

Port, Robert, Jonathan Dalby \& Michael O'Dell (1987). Evidence for mora timing in Japanese. Journal of the Acoustical Society of America 81, 1574-1585.

Poser, William (1990). Evidence for foot structure in Japanese. Language 66, 78-105.

van Rooy, Bertus, Daan Wissing \& Dwayne D. Paschall (2003). Demystifying incomplete neutralization during final devoicing. Southern African Linguistics and Applied Language Studies 21, 49-66.

Slowiaczek, Louisa M. \& Daniel Dinnsen (1985). On the neutralizing status of Polish word-final devoicing. Journal of Phonetics 13, 325-341.

Steriade, Donca (2000). Paradigm uniformity and the phonetics-phonology boundary. Pierrehumbert, Janet \& Michael Broe (eds.), Papers in Laboratory Phonology V: Acquisition and the Lexicon, Cambridge University Press, chap. 22, 313-334.

Warner, Natasha, Allard Jongman, Joan Sereno \& Rachèl Kemps (2004). Incomplete neutralization and other subphonemic durational differences in production and perception: Evidence from Dutch. Journal of Phonetics 32, 251-276.

Yu, Alan C. L. (2007). Understanding near mergers: The case of morphological tone in cantonese. Phonology 24, 187214.

Yu, Alan C. L. (2011). Contrast reduction. Goldsmith, John, Jason Riggle \& Alan C. L. Yu (eds.), The Handbook of Phonological Theory, Second Edition, Blackwell, chap. 9, 291-318.

Zsiga, Elizabeth (2000). Phonetic alignment constraints: Consonant overlap and palatalization in English and Russian. Journal of Phonetics 28, 69-102. 